\title{
Chitosan as a Hepato-Protective Agent against Single Oral Dose of Dioxin
}

\author{
Hanaa M. Abd El-Fattah ${ }^{1}$, Abdel- Kader Z.M. ${ }^{1}$, Hassnin $\quad$ E. A. ${ }^{2}$, \\ Mohamed K. Abd El-Rahman ${ }^{2}$, and Lamiaa E. Hassan ${ }^{2}$ \\ 1. Women's College Ain Shamms University, Egypt \\ ${ }^{2}$ : National Nutrition Institute, Ministry of Health, Egypt
}

\begin{abstract}
:
Investigations revealed that tetrachlorodibenzo-p-dioxin (TCDD) induces hepatic damage. Chitosan exhibits antioxidant properties and supplementations with antioxidants can influence hepatotoxicity. We evaluate effect of dietary low molecular weight chitosan (106-110 kilodaltons) in 3 multiplied doses (1.2, 2.4 and $3.6 \mathrm{~g} / \mathrm{kg}$ diet) against hepato toxic effects caused by a single oral dose (5 $\mathrm{g} \mathrm{TCDD} / \mathrm{kg}$ body weight) for 6 weeks in adult male albino rats. TCDD decreased body weight gain, food intake, feeding efficiency ratio, serum albumin and albumin / globulin ratio. While it caused an increase in liver relative weight, serum total protein, globulin, aspartate and alanine amino transferases and alkaline phosphatase. Also, TCDD caused basophilic hyper chromatic nuclei, hepatic degeneration and fibrosis. Chitosan alone showed a significant positive effect in measured items except feed intake, body weight gain and feed efficiency ratio. Also it alleviated most of biochemical and histological hepatotoxic effects of dioxin. Chitosan is safe as a dietary supplement in rat's diet and can mitigate the hepatotoxic effects of TCDD by controlling the antioxidant status and free radicals production.
\end{abstract}

Keywords: antioxidants, chitosan, hepatotoxicity, Sprague Dawley rats, TCDD.

\section{Introduction}

Persistent organic pollutants (POPs) include a variety of man-made chemicals, including 75 polychlorinated dibenzo-p-dioxins (PCDDs), 135 polychlorinated dibenzofurans (PCDFs) and 209 polychlorinated biphenyls that have been highlighted by international organizations as chemicals of concern [1]. Dioxin is one of the most widespread, persistent and highly toxic environmental pollutants that known to cause a variety of adverse effects in human and wild animals [2]. Dioxins came into the public eye for the first time in 1982 due to the explosion at the factory in Seveso, Italy. Dioxin is formed naturally during volcanic eruptions and in forest fires, dioxins are produced during synthesis of chlorinated herbicides and pesticides, in waste and medical incinerators and in pulp and paper manufacturing industry [3]. Persistent and hydrophobic nature of dioxins helps their accumulation in soil due to redistribution in environment by dust re-suspension [4].Human populations' direct exposure to dioxin occurs through food chain. [5].The most potent and widespread environmental dioxin congener is 2,3,7,8 tetrachlorodibenzo-p-dioxin (TCDD) with many toxic effects, including endocrine disruption, reproductive dysfunction, immunotoxicity, liver damage, and cancer [6]. The main target organ for 2, 3, 7, 8-TCDD differ among animal species but usually affected is the liver [7] Major toxicities of TCDD are initiated by its binding to aryl hydrocarbon receptor (AHR), a ligand-activated transcription factor that regulates expression of numerous genes whom dysregulation leads to major toxicities such as wasting, hepatotoxicity, and lethality [8]. Since environmental dioxin exposure cannot easily be eliminated, it is important to find a safe methodology to be taken chronically to combat unavoidable ingestion of dioxin [2].

Chitosan is an amino polysaccharide derived from deacetylation of chitin of arthropods and insects exoskeleton and considered a dietary fiber due to indigestibility by digestive enzymes [9]. Chitosan contains three types of reactive functional groups, an amino/acetamido group as well as both primary and secondary hydroxyl groups at C-2, C-3 and C-6 positions, respectively [10]. Chitosan is a cationic polysaccharide, which has many functions in fields of bio medicinal and pharmaceutical products, food preservation and microbial mitigation [11]. Chitosan biodegradation releases non-toxic oligosaccharides as it is being hydrolyzed to ultralow molecular weight chains that pass across intestinal epithelial barrier and become excreted in urine [12]. No clinically significant adverse effects of chitosan have been reported to date, but mild nausea and constipation have commonly occurred particularly at higher doses [13]. 


\section{Materials And Methods}

II.1 Materials:

Low molecular weight (LMW) chitosan (106-110 KDa) was obtained from Misr Chemia Company, Egypt. 2,3,7,8 tetrachlorodibenzo-p- dioxin (TCDD) was purchased from Willington laboratories, Canada, (CAS No. 1746-01-6) with purity $>99 \%$, soluble in dimethyl sulfoxide (DMSO).

\section{II.2 Experimental animals:}

Eighty male albino rats, Sprague Dawley strain weighing 120-140 g were obtained from The National Nutrition Institute animal house and kept individually in stainless steel cages in constant environmental conditions.

\section{II.3 Diets:}

Basal diet was prepared according to Ain-93M formulation [14]. Three diets contained basal diets were supplemented with 1.2, 2.4 and $3.6 \mathrm{~g}$ (LMW) chitosan/kg diet (chitosan 1, 2 and 3 respectively).

\section{II.4 Experimental design:}

After one week acclimatization period on basal diet, rats were divided into eight groups (ten rats in each group). $\boldsymbol{G} \boldsymbol{1}$ (-ve control): received basal diet. $\boldsymbol{G} \boldsymbol{2}$ (+ve TCDD): received basal diet and gavaged orally once with $5 \mu \mathrm{g}$ TCDD $/ \mathrm{kg}$ Bwt at zero time of the experiment. $\boldsymbol{G} 3, \boldsymbol{G} \boldsymbol{4}$ and $\boldsymbol{G} \boldsymbol{5}$ were fed basal diets supplemented with 1.2, 2.4 and $3.6 \mathrm{~g}$ (LMW) chitosan/kg diet (chitosan 1, 2 and 3, respectively). $\boldsymbol{G 6}, \boldsymbol{G} 7$ and $\boldsymbol{G 8}$ were gavaged orally once with $5 \mu \mathrm{g} \mathrm{TCDD} / \mathrm{kg}$ Bwt and fed basal diet supplemented with 1.2, 2.4 or $3.6 \mathrm{~g} \mathrm{LMW}$ chitosan $/ \mathrm{kg}$ diet (TCDD + chitosan 1, 2 and 3 respectively). Animals were handled according to [15]. Animals and diets were weighed twice weekly to determine Bwt change, feed intake and feed efficiency ratio \{change in Bwt/total food intake\} for each group [16]. After 6 weeks, rats were sacrificed by ether anesthesia. Hepatic portal vein blood was collected into heparin free centrifuge tubes, to collect serum by centrifugation at $4000 \mathrm{rpm}$ for 15 minutes. Livers were plotted free of blood and adhering fats then dried between filter papers and weighed. A part of each liver was dipped in 10\% formalin for histopathological assessment according to [17].Other samples were kept at $-80{ }^{\circ} \mathrm{C}$ until analysis.

\section{II.5 Biochemical analysis:}

Serum aminotransferases (ALT and AST) were determined according to [18, 19]. Alkaline phosphatase (Alk-P) was determined quantitatively according to [20]. Serum total protein (TP) and albumin were measured calorimetrically according to [21]. Globulin was obtained by this formula \{TP - albumin $\}$ then, albumin is subdivided on globulin to obtain $\mathrm{A} / \mathrm{G}$ ratio according to [22].

\section{II.6 Statistics:}

All data were analyzed using student's $t$ test, expressed as mean ${ }_{+}$SE and groups were compared using one - way analysis (ANOVA).

\section{Results And Discussion}

III.1 Effect of chitosan on feed intake, body weight change (Bwt), feed efficiency ratio (FER) and liver relative weight:

Data in table (1) showed a highly significant decrease in feed intake, body weight and FER with a highly significant increase in relative weight of liver at $(p \leq 0.01)$ in $\boldsymbol{G} \mathbf{2}$ (+ve TCDD) when compared with $\boldsymbol{G 1}$ (-ve control). Feeding chitosan 1 alone in $\boldsymbol{G} 3$ caused a significant decrease in Bwt at $(p \leq 0.05)$ and a highly significant decrease in FER at $(p \leq 0.01)$ when compared with $\boldsymbol{G} \mathbf{1}$ (-ve control). While chitosan 2 and 3 in $\boldsymbol{G} 4$ and $\boldsymbol{G 5}$ caused a highly significant decrease in Bwt and FER at $(p \leq 0.01)$ if compared with $\boldsymbol{G 1}$ (-ve control). Comparing $\boldsymbol{G} 7$ and $\boldsymbol{G} \boldsymbol{8}$ (TCDD + chitosan 2 and 3) with $\boldsymbol{G} \boldsymbol{2}$ (+ve TCDD), a significant decrease in liver relative weight at $(p \leq 0.01)$ could be noticed in $\boldsymbol{G} 7$ and $\boldsymbol{G} \boldsymbol{8}$ with a highly significant increase in FER at $(p \leq 0.01)$ in $\boldsymbol{G} \boldsymbol{8}$ only. Our results agreed with [23] who found that Bwt, activity and feed consumption of rats given intragastric $10 \mu \mathrm{g}$ TCDD $/ \mathrm{kg}$ Bwt decreased from the $5^{\text {th }}$ day if compared with control rats. That was explained by [24] who suggested that TCDD-induced wasting syndrome is associated with serum lipids increase and disordered lipid distribution. Also, Relative liver weight increased due to fatty vacuolization in rats gavaged with 10 or $30 \mu \mathrm{g}$ $\mathrm{TCDD} / \mathrm{kg}$, respectively for 1 week [25]. Moreover, it was found that liver weights decreased by $60 \%$ in animals received $500 \mathrm{mg}$ chitosan oligosaccharide II/ $/ \mathrm{kg}$ for 14 consecutive days after an oral dose of $25 \mu \mathrm{g} \mathrm{TCDD} / \mathrm{kg}$ Bwt.[26]. Body and liver weights of rats that were fed AIN-93G diet for $18 \mathrm{~d}$ containing $0.125 \mathrm{~g}$ cholesterol and $10 \mathrm{~g}$ chitosan/100g diet were significantly lower than controls[27]. Similarly, dietary $5 \%$ chitosan to adult SD rats for 6 weeks caused a significant decrease in Bwt and organs weights [28]. 


\section{III.2 Effect of chitosan on liver function enzymes:}

Table (2) showed a highly significant increase in serum ALT, AST and ALK- P at $(p \leq 0.01)$ in $\boldsymbol{G} 2$ (+ve TCDD) in relation to $\boldsymbol{G} \boldsymbol{1}$ (-ve control). In $\boldsymbol{G} 3$ (chitosan1) caused a significant decrease in ALT at $(p \leq 0.05)$ and a highly significant decrease in AST at $(p \leq 0.01)$, while in $\boldsymbol{G} \mathbf{4}$ and $\boldsymbol{G 5}$ (chitosan2 and 3); a highly significant decrease in ALT, AST and ALK- P at $(p \leq 0.01)$ if compared with $\boldsymbol{G 1}$ (-ve control). There is a highly significant

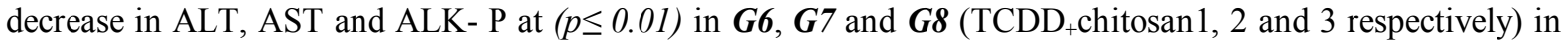
relation to $\boldsymbol{G} \boldsymbol{2}$ (+ve TCDD). Elevation of liver enzymes is used as marker of liver injury due to their leakage from damaged cells [29]. Our results are compatible with [7] who stated that ALT increased steadily after $24 \mathrm{~h}$ from giving mice 10 or $30 \mu \mathrm{g} \mathrm{TCDD} / \mathrm{kg}$ to a maximum of $260 \%$ relative to controls at $168 \mathrm{~h}$, indicative of mild liver injury. Also, a significant elevation of AST was found in adult female rats given a single oral dose of 0.03 $\mu \mathrm{g}$ TCDD $/ \mathrm{kg}$ Bwt. [30]. When male Wister rats were given 0.75 to $8 \mu \mathrm{g} \mathrm{TCDD} / \mathrm{kg}$ Bwt interperitoneally, a highly significant increase in ALT occurred in 21 days [31]. Furthermore, it was found that adult male albino rats pretreated with $200 \mathrm{mg}$ chitosan/ $\mathrm{kg}$ Bwt orally for 21 consecutive days prior to intraperitoneal $20 \mathrm{mg}$ carbon tetra chloride/kg Bwt significantly ameliorated liver function effectively by decreasing ALT and AST as illustrated by [32]. ALT and AST activity slightly decreased in male SD rats fed hypercholesterolemia induced diets supplemented with 1.2, 2.4 and $3.6 \mathrm{~g}$ chitosan $/ \mathrm{kg}$ diet for 4 weeks [33].

\section{III.3 Effect of chitosan on total protein (TP), albumin, globulin and albumin/globulin ratio (A/G):}

Table (3) showed a highly significant increase in TP and globulin with a highly significant decrease in albumin and A/G ratio at $(p \leq 0.01)$ in $\boldsymbol{G} 2$ (+ve TCDD) in relation to $\boldsymbol{G} \mathbf{1}$ (-ve control). Chitosan3 alone in $\boldsymbol{G 5}$ caused a highly significant increase in $\mathrm{A} / \mathrm{G}$ ratio at $(p \leq 0.01)$ in relation to $\boldsymbol{G 1}$ (-ve control). Rats in $\boldsymbol{G 6}$ $\left(\mathrm{TCDD}_{+}\right.$chitosan1) had a significant decrease in globulin at $(p \leq 0.05)$ and a highly significant increase in $\mathrm{A} / \mathrm{G}$ ratio at $(p \leq 0.05)$ in relation to $\boldsymbol{G} \boldsymbol{2}$ (+ve TCDD). In $\boldsymbol{G} 7$ (TCDD + chitosan2), results showed a highly significant decrease in globulin at $(p \leq 0.01)$ with a highly significant increase in $\mathrm{A} / \mathrm{G}$ ratio when compared with $\boldsymbol{G} \boldsymbol{2}(+\mathrm{Ve}$ $\mathrm{TCDD}$ ). Feeding chitosan to rats in $\boldsymbol{G} \boldsymbol{8}$ (TCDD $\mathrm{T}_{+}$chitosan3) caused a highly significant increase in albumin and $\mathrm{A} / \mathrm{G}$ ratio at $(p \leq 0.01)$ with a significant decrease in TP at $(p \leq 0.05)$ and a highly significant decrease in globulin at $(p \leq 0.01)$ in relation to $\boldsymbol{G} \mathbf{2}(+\mathrm{ve}$ TCDD). Our results are compatible with $\mathbf{3 4 ]}$ who noticed that serum TP and globulin increased significantly in rats given single oral dose of 0.4 and $40 \mu \mathrm{g} T \mathrm{TDD} / \mathrm{kg}$ Bwt for 7 days due to hepatotoxicity. Also, TCDD-related decrease in serum albumin was found to be secondary to the hepatotoxic effect of TCDD caused in most experimental animals [35]. TP increased significantly in Syrian hamster male rats (the least sensitive mammalian species to TCDD lethal effects) given $3000 \mu \mathrm{g}$ TCDD/ $\mathrm{kg} \mathrm{Bwt}$ interperitoneally [36]. TP and globulin increase may be the result of hypertrophic changes in liver and proliferation of endoplasmic reticulum implied by obvious cellular hypertrophy [37]. Contrary to that, an increase in serum albumin in female SD rats gavaged by 250-1000 $\mathrm{ng}$ TCDD $/ \mathrm{kg}$ Bwt for 28 days [38].

\section{III.4 Effect of chitosan on liver histopathology:}

Figures (1-8) illustrates the effect of feeding rats control diet alone or plus chitosan for 6 weeks with or without single oral dose of $5 \mu \mathrm{g} \mathrm{TCDD/kg} \mathrm{Bwt} \mathrm{in} \mathrm{liver} \mathrm{histology.} \mathrm{Fig.(1)} \mathrm{showing} \mathrm{normal} \mathrm{hepatic} \mathrm{lobule}$ composed of a central vein and masses of liver cells arranged in the form of cords radiating from the central vein and separated from each other by blood sinusoids. The hepatocytes were polyhedral with eosinophilic cytoplasm. Their nuclei were mostly large, open face, with prominent one or more nucleoli G1 (-ve control). In Fig. (2) there is a marked hepatocytes vacuolar degeneration plus chronic inflammatory cells with mild fibrosis and fibrous septa extension. The bottom of the picture showing hepatocytes with deeply basophilic, hyper chromatic nuclei and increased nuclear: cytoplasm ratio in rats gavaged once with $5 \mu \mathrm{g}$ dioxin / $\mathrm{kg}$ Bwt $\boldsymbol{G} \boldsymbol{2}(+\mathrm{ve}$ TCDD).

No obvious histological changes were noticed in livers of rats in $\boldsymbol{G 3}, \boldsymbol{G} 4$ and $\boldsymbol{G 5}$ (chitosan 1, 2 and 3 respectively) See Fig. (3-5) with ordinary hepatocytes surrounding central vein within normal architectural. Fig. (6) showing fibrous tissue septa between hepatocytes with scattered few chronic inflammatory cells and moderate degeneration was noticed. Normo chromatic nuclei with ordinary nuclear: cytoplasmic ratio G6 (TCDD + chitosan1). Fig. (7) showing degenerated hepatocytes with diminished vacuolar degeneration within cytoplasm. Nuclei showed semi normo chromatic with ordinary nuclear: cytoplasmic ratio $G 7$ (TCDD + chitosan2). Fig. (8) showing residual minimal micro vacuolar degeneration within hepatocytes. Binucleated hepatocytes were still seen in rat liver in $\boldsymbol{G 8}\left(\mathrm{TCDD}_{+}\right.$chitosan3).

Our results are in agreement with [39] who stated that livers of male mice given $5.0 \mu \mathrm{g}$ TCDD $/ \mathrm{kg}$ showed massive infiltration and increased necrosis with inflammatory cells. Also, rats exposed to TCDD exhibited minimal to moderate hepatocellular hypertrophy in centriacinar regions at 24,72 , and $168 \mathrm{~h}$. The cytoplasm of these enlarged hepatocytes was more granular and eosinophilic and less vacuolated compared to centriacinar hepatocytes of control rats. The severity of these lesions increased with time after exposure and is consistent with reported effects in male SD rats treated with TCDD [34]. In rats received $8 \mu \mathrm{g}$ TCDD/ kg Bwt 
hepatic lobules revealed parenchymal degeneration and vacuolization of hepatocytes. Moreover, the number of mitoses was higher and lipid deposits were found in macrophages together with early signs of hepatocyte steatosis [31]. Dietary $3 \mathrm{mg}$ chitosan $/ \mathrm{kg}$ Bwt against $3 \mathrm{ml} \mathrm{CCl}_{4} / \mathrm{kg}$ through gavage for $24 \mathrm{hrs}$ protected rat liver and showed only mild lesions with a few necrotic hepatocytes in the centrolobular area, and less inflammatory infiltrate [32].Also, when mice were administrated interperitoneally $1 \mathrm{mg}$ chitosan/kg Bwt./day, liver central vein dilation caused by $1 \mathrm{mg}$ nicotine/kg Bwt /day) for 7 days decreased significantly [40].

\section{Tables And Figures}

Table (1) Effect of dietary chitosan on feed intake, body weight change (Bwt), feed efficiency ratio (FER) and liver relative weight in rats treated or not treated with single oral dose TCDD for 6 weeks.

\begin{tabular}{|c|c|c|c|c|c|c|c|c|}
\hline Item & $\begin{array}{l}G 1 \\
-v e \\
\text { control }\end{array}$ & $\begin{array}{c}G 2 \\
\text { tve } \\
T C D D\end{array}$ & $\underset{\text { chitosan1 }}{\text { G3 }}$ & $\underset{\text { chitosan2 }}{G 4}$ & $\begin{array}{c}\text { G5 } \\
\text { chitosan3 }\end{array}$ & $\begin{array}{c}\text { GCD } \\
\underset{T C D D}{+} \\
\underset{\text { chitosan1 }}{+}\end{array}$ & $\begin{array}{c}\underset{T C D D}{G 7} \\
\underset{\text { Chitosan2 }}{+}\end{array}$ & $\begin{array}{c}G 8 \\
T C D D \\
\underset{\text { chitosan3 }}{+}\end{array}$ \\
\hline $\begin{array}{c}\text { Feed intake } \\
\text { (g/feeding period) }\end{array}$ & $443.8+14.6$ & $373.0_{+} 11.1^{\text {** }}$ & $447+10.2$ & $457.1_{+} 4.7$ & $460_{+} 14.2$ & $394+9.8$ & $395_{+} 14.7$ & $398+13.7$ \\
\hline $\begin{array}{c}\text { Bwt. change } \\
\text { (g/feeding period) }\end{array}$ & $90.6+3.5$ & $12.5+3.7^{* * *}$ & $30.3+2.5^{*}$ & $28.8+1.6^{* *}$ & $22.8+1.3^{* *}$ & $12.6+2.3$ & $19.3_{+} 1.9$ & $2.7+2.6$ \\
\hline$F E R$ & $0.21_{+} 0.01$ & $0.04_{+} 0.01^{* *}$ & $0.17+0.01^{* *}$ & $0.16+0.02^{* *}$ & $0.15_{+} 0.01^{* *}$ & $0.07+0.01$ & $0.08_{+} 0.01$ & $0.1_{+} 0.01^{\# \#}$ \\
\hline $\begin{array}{c}\text { Liver relative } \\
\underset{(g \%)}{\text { weight }}\end{array}$ & $3.5+0.14$ & $4.74_{+} 0.22^{* *}$ & $3.25_{+} 0.06$ & $3.44_{+} 0.12$ & $3.74+0.23$ & $4.64_{+} 0.21$ & $4.18_{+} 0.25^{\#}$ & $3.92{ }_{+} 0.20^{\# \#}$ \\
\hline
\end{tabular}

Data are expressed as mean $+\mathrm{SE}$

${ }^{* * *}$ : significant difference from (-ve) control at $\mathrm{P} \leq 0.05$ and $\mathrm{P} \leq 0.01$, respectively.

$\# /{ }^{\# \#}$ : significant difference from (+ve) control at $\mathrm{P} \leq 0.05$ and $\mathrm{P} \leq 0.01$, respectively.

Table (2) Effect of dietary chitosan on serum alanine aminotransferase (ALT), aspartate aminotransferase (AST) and alkaline in rats treated or not treated with single oral dose of TCDD for 6 weeks.

\begin{tabular}{|c|c|c|c|c|c|c|c|c|}
\hline Group & $\begin{array}{c}G 1 \\
\text { Ge } \\
\text { control }\end{array}$ & $\begin{array}{c}G 2 \\
\text { tve } \\
T C D D\end{array}$ & $\underset{\text { chitosan1 }}{G 3}$ & $\underset{\text { chitosan2 }}{G 4}$ & $\underset{\text { chitosan3 }}{\text { G5 }}$ & $\begin{array}{c}G 6 \\
\text { TCDD } \\
+ \\
\text { chitosan1 }\end{array}$ & $\begin{array}{c}G 7 \\
T C D D \\
+ \\
\text { chitosan2 }\end{array}$ & $\begin{array}{c}G 8 \\
T C D D \\
+ \\
+ \\
\text { chitosan3 }\end{array}$ \\
\hline $\begin{array}{l}A L T \\
(U / L)\end{array}$ & $14.98+0.31$ & $48.1+0.75^{* *}$ & $13.4_{+} 0.49^{*}$ & $12.1+0.36^{* *}$ & $8.13+0.37^{* *}$ & $31.7+0.61$ & $26.6+0.56^{\# \#}$ & $20.7+0.61^{\# \#}$ \\
\hline $\begin{array}{l}A S T \\
(U / L)\end{array}$ & $23.8+0.61$ & $84.4_{+} 0.41^{* *}$ & $19.7+0.42^{* *}$ & $18.4_{+} 0.34^{* *}$ & $15.9+0.41^{* *}$ & $78.5_{+} 0.4^{\# \#}$ & $52.8+0.59^{\# \#}$ & $47.8+0.60^{\# \#}$ \\
\hline $\begin{array}{c}A L K-P \\
(U / L)\end{array}$ & $23.7+0.51$ & $129.0_{+} 1.33^{* *}$ & $22.3+0.99$ & $20.8+0.87^{* *}$ & $18.7_{+} 0.59^{* *}$ & $115.0_{+} 0.73^{\# \#}$ & $83.7+1.21^{\# \#}$ & $75.3+0.78^{\# \#}$ \\
\hline
\end{tabular}

Data are expressed as mean $+\mathrm{SE}$

${ }^{* * *}$ : significant difference from (-ve) control at $\mathrm{P} \leq 0.05$ and $\mathrm{P} \leq 0.01$, respectively.

$\#$ \#\#\# significant difference from $(+\mathrm{Ve})$ control at $\mathrm{P} \leq 0.05$ and $\mathrm{P} \leq 0.01$, respectively.

Table (3) Effect of chitosan on serum total protein (TP), albumin, globulin and albumin/globulin ratio (A/G) in rats treated or not treated with single oral dose of TCDD for 6 weeks

\begin{tabular}{|c|c|c|c|c|c|c|c|c|}
\hline Iten & $\begin{array}{c}G 1 \\
-v e \\
\text { control }\end{array}$ & $\begin{array}{c}G 2 \\
+v e \\
T C D D\end{array}$ & $\begin{array}{c}\text { G3 } \\
\text { chitosan1 }\end{array}$ & $\begin{array}{c}G 4 \\
\text { chitosan2 }\end{array}$ & $\begin{array}{c}\text { G5 } \\
\text { chitosan3 }\end{array}$ & $\begin{array}{c}\text { G6 } \\
\text { TCDD } \\
+ \\
\text { chitosan1 }\end{array}$ & $\begin{array}{c}G 7 \\
T C D D \\
+ \\
\text { chitosan2 }\end{array}$ & $\begin{array}{c}G 8 \\
T C D D \\
+ \\
\text { chitosan3 }\end{array}$ \\
\hline $\begin{array}{c}T P \\
(g / d l)\end{array}$ & $5.57+0.21$ & $7.54+0.15 * *$ & $5.28+0.28$ & $5.38+0.26$ & $5.53+0.24$ & $7.23+0.21$ & $7.08+0.31$ & $6.77+0.39^{\#}$ \\
\hline $\begin{array}{c}\text { Albumin } \\
(\mathrm{g} / \mathrm{dl})\end{array}$ & $3.60+0.10$ & $1.88+0.24 * *$ & $3.63+0.16$ & $3.68+0.18$ & $3.71_{+} 0.09$ & $2.07_{+} 0.15$ & $2.29+0.16$ & $2.56_{+} 0.12^{\# \#}$ \\
\hline $\begin{array}{c}\text { Globulin } \\
(\mathrm{g} / \mathrm{dl})\end{array}$ & $1.97+0.21$ & $5.66_{+} 0.27 * *$ & $1.65_{+} 0.30$ & $1.70+0.28$ & $1.82+0.29$ & $5.16_{+} 0.27^{\#}$ & $4.79+0.37^{\# \#}$ & $4.21_{+} 0.45^{\# \#}$ \\
\hline$A / G$ ratio & $2.02+0.21$ & $0.36+0.06 * *$ & $2.78+0.27$ & $2.65+0.24$ & $3.37+1.27 * *$ & $0.42+0.05^{\# \#}$ & $0.49_{+} 0.04^{\# \#}$ & $0.64_{+} 0.06^{\# \#}$ \\
\hline
\end{tabular}

Data are expressed as mean $+\mathrm{SE}$

${ }^{* * * *}$ : significant difference from (-ve) control at $\mathrm{P} \leq 0.05$ and $\mathrm{P} \leq 0.01$, respectively.

\#/\#\# : significant difference from (+ve) control at $\mathrm{P} \leq 0.05$ and $\mathrm{P} \leq 0.01$, respectively. 


\section{Liver histology}

Fig. 1

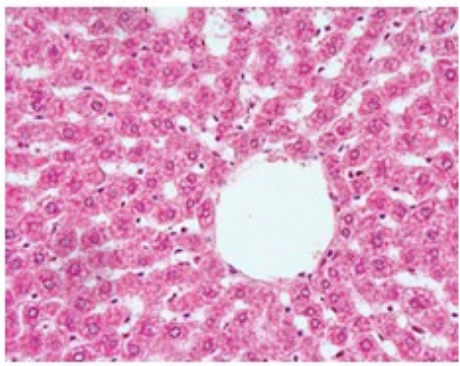

Fig.3

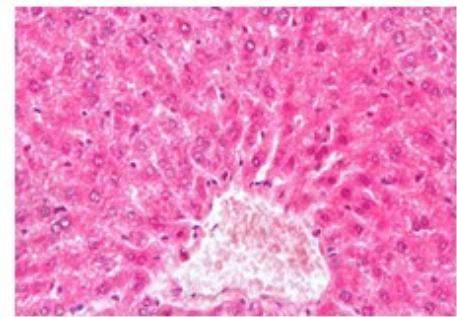

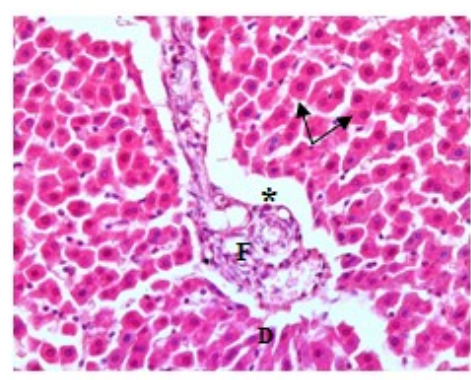

Fig.2

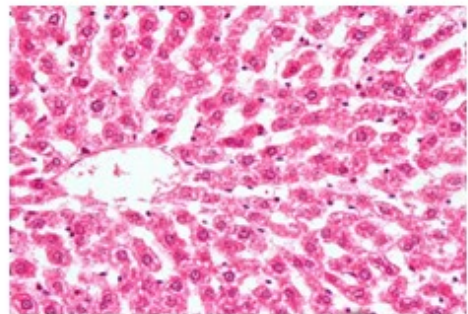

Fig.4

Figure (1): Section of control rat liver $\boldsymbol{G 1}$. Figure (2) Section of dioxin +ve control liver $\boldsymbol{G} 2$.

Arrows: basophilic hyper chromatic nuclei. D: hepatic degeneration. F: fibrosis. **: fibrous septa.

Figures (3and4) Sections of rat liver fed chitosan (1 or 2) alone in G3and G4. (H\&E X400).

Fig.5
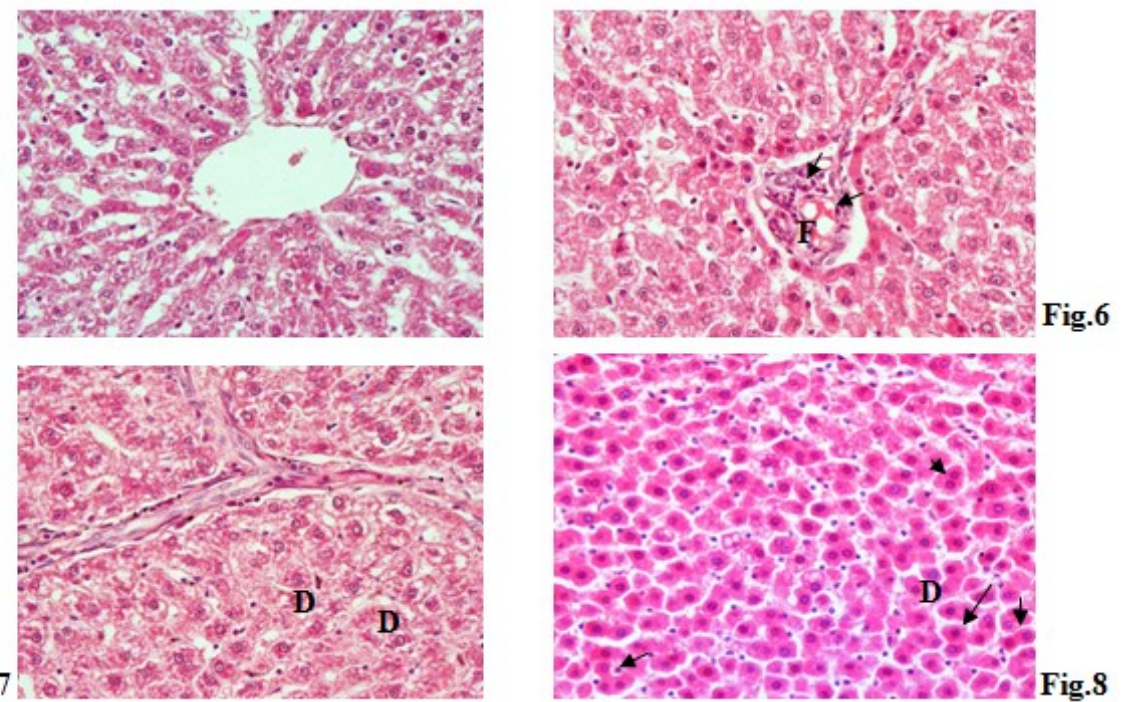

Figure (5) Section of rat liver fed chitosan (3) alone in G5. Figure (6) Section of rat liver fed chitosan (1) and dioxin in G6

(Arrow): inflammatory cells. F: fibrosis. D: degeneration. Figure (7) Section of rat liver fed chitosan (2) and dioxin in $\boldsymbol{G} 7$

D: degenerated hepatocytes. Figure (8) Section of rat liver fed chitosan (3) and dioxin in $\boldsymbol{G 8}$ D: mild degeneration. (Arrows): binucleated hepatocytes. (H\&E X400)

\section{Conclusion}

Dioxin is one of the most widespread, persistent and highly toxic environmental pollutants that known to cause a variety of adverse effects in human and wild animals It is clear that, there are few methods have been explored for the remediation of animals exposed to dioxins using nutritional treatments. Reducing TCDD mediated hepato toxic effects resulted from dietary exposure is an effective strategy for protection. This study concluded that a single oral dose of $5 \mu \mathrm{g}$ 2,3,7,8 tetra chloro dibenzo-p- dioxin has many chronic harmful effects on liver functions and histology. Also, it concludes that addition of chitosan as $1.2,2.4$ and $3.6 \mathrm{~g} / \mathrm{kg}$ diet is safe for male albino rats and can amend most of affected features due to chitosan antioxidative properties and its hydroxyl radical scavenging ability. 


\section{References}

[1] A. Abelsohn, L. Gibson, D. Sanborn and E. Weir . Identifying and managing adverse environmental health effects of Persistent organic pollutants. Can Med Assoc J. 166, 2002, 1549-54.

[2] T. Ishida, M. Ishizaki, S. Tsutsumi, Y. Ishii and H. Yamada. Piperine, a paper ingredient improves the hepatic increase in free fatty acids caused by 2, 3, 7, 8-tetrachlorodibenzo-p-dioxin.J Health Sci. 54, 2008. 551- 58.

[3] S. Chang S. Recent developments in microbial biotransformation and biodegradation of dioxins. J Mol Microbiol Biotechnol. 15, 2008. 152- 71 .

[4] O. Kjeller and C. Rappe. . Time trends in levels, patterns, and profiles for polychlorinated dibenzo-p-dioxins, dibenzofurans, and biphenyls in a sediment core from the Baltic Proper. Environ Sci Technol. 29, 1995. 346- 55.

[5] H. Sean and A. Lesa. Dioxin risks in perspective: past, present, and future. Regul Toxicol Pharmacol. 37, $2003.202-217$.

[6] S. Kim, E. Henery, D. Kim, Y. Kim, K. Shin, M. Han, T. Lee, J. Kang, T. Gasiewicz,S. Ryu and P. Suh . . Novel compound 2methyl-2H-pyrazole-3-carboxylic acid (2-methyl-4-o-tolylazo-phenyl)-amide (CH-223191) prevents 2, 3, 7, 8-TCDD-induced toxicity by antagonizing the aryl hydrocarbon receptor. Mol Pharmacol . 69, 2006. 1871-87.

[7] D. Boverhof, L. Burgoon, T. Colleen, B. Sharratt, B. Chittim, J. Harkema, D. Mendrick and T. Zacharewski T. Comparative toxicogenomic analysis of the hepatotoxic effects of TCDD in Sprague Dawley rats and C57bl/6 mice. Toxicol Sci. 94, 2006, 398416.

[8] T. Ikuta, Y. Kobayash and K. Kawajiri . Phosphorylation of nuclear localization signal inhibits the ligand-dependent nuclear import of aryl hydrocarbon receptor. Biochem Biophys Res Commun. 317, 2004. 545-50.

[9] N. Kohda S. , Inoue T. Noda and T. Saito. Effects of a chitosan intake on the fecal excretion of dioxins and fat in rats. Biosci Biotech Biochemist. 76, 2012. 1544- 48.

[10] X. Wenshui, L. Ping, Z. Jiali and C. Jie. Biological activities of chitosan and chitooligosaccharides. Food Hydrocolloids. $25,2011$. 170- 79 .

[11] J. Vinsova and E. Vavrikova. Recent advances in drugs and prodrugs design of chitosan. Curr Pharmaco Des. 14, 2008. 1311-26.

[12] Y. Chae, K. Jang and W. Nah. Influence of molecular weight on oral absorption of water soluble chitosans. J Control Release. 102, 2005. 383- 94 .

[13] M. Pittler, N. Abbott, E. Harkness and E. Ernst. Randomized, double- blind trial of chitosan for body weight reduction. Eur J Clin Nutr. 53, 1999. 379-81.

[14] P. Reeves, F. Nielsen and G. Fahey. Ain-93 purified diets for laboratory rodents: final report of the American institute of nutrition ad hoc writing committee on the reformulation of the ain-76a rodent diet. J Nutr. 123, 1993. 1939-51.

[15] CPCSEA. Committee for the Purpose of Control and Supervision of Experiments on Animals/CH/RF/ACK- 29-07, India. 2003.

[16] J. Proll , K. Petzke, I. Ezeagu and C. Metges. Low nutritional unconventional tropical crop seeds in rats. J Nutr. 128, 1998. 201422 .

[17] D. Bancroft, A. Steves and R. Tuner. Theory and practice of histopathological techniques. (Churchill living stones, Edinburgh, London, Melbourn, 4th edn.)1996.

[18] H. Bergmeyer, M. Horder and R. Rej. Approved recommendation 1985 on IFCC methods for the measurement of catalytic concentration of alanine amino transferase. J Clin Chem Clin Bioch. 24, 1986. 481 - 89.

[19] J. Wilkinson. 1976.Principles and practice for diagnostic enzymology. Year book medical Publishers. Edward Arnold. London. pp. $241-493$.

[20] U. Haussament. Quantitative determination of serum alkaline phosphatase. Clin Acta. 35, 1977, $271-3$.

[21] S. Christensen and Anderson S. Proteins, clinical chemistry: Concepts and applications. (W. B sunders eds. Philadelphia, USA) 1983, P. 188.

[22] T. Matsuzawa, Y. Hayashi, M. Nomura, T. Unno, T. Igarashi, T. Furuya, K. Sekita, A. Ono, Y. Kurokawa and Y. Hayashi. A survey of the values of clinical chemistry parameters for a common rat blood sample in ninety eight Japanese laboratories. Toxicol Sci. 22, 1997. 25- 45.

[23] G. Lu, Y. Wang, S. Peng, L. Zou, H. Tan, G. Liu,Z. Fu, X. Wang and J. Zha. Combined effects of repeated administration of 2, 3, 7, 8-tetrachlorodibenzo-p-dioxin and polychlorinated biphenyls on kidneys of male rats. Arch Environ Contam Toxicol 57, 2009. 767- 76

[24] C. Lee, Y. Yao, H. Chen, Y. Guo and H. Su. Fatty liver and hepatic function for residents with markedly high serum PCDD/Fs levels in Taiwan. J Toxicol Environ Health Part A. 69, 2006. 367- 80.

[25] D. Boverhof, L. Burgoon, T. Collen, C. Brock, J. Harkema, D. Jump and T. Zacharewski. Temporal and dose dependent hepatic gene expression patterns in mice provide new insights into TCDD mediated hepatotoxicity. Toxicol Sci. 85, $2005.1063-84$.

[26] S. Yun-Hee, P. In-Kook, M. Il-Soo, C. Hyeun- Wook, P. In-Kyung and N. Kyung-Soo. Effect of chitosan oligosaccharide on 2, 3, 7, 8-tetrachlorodibenzo-p- dioxin-induced oxidative stress in mice. Biol Pharm Bull 25, 2002. 1161- 64.

[27] M. Gallaher, J. Munion, R. Hesslink and D. Gallaher. Cholesterol reduction by glucomannan and chitosan is mediated by changes in cholesterol absorption and bile acid and fat excretion in rats. J Nutr, 130, 2000. 2753-59.

[28] B. Lamiaa. Hypolipidemic and antiatherogenic effects of dietary chitosan and wheat bran in high fat- high cholesterol fed rats. Austr J Bas Appl Sci. 5, 2011. 30-37.

[29] E. Giannini, T. Roberto and S. Vincenzo. Liver enzyme alteration: a guide for clinicians. Can Med Associa J. 172, 2005. 367-79.

[30] S. Ulla, T. Jouni, T. Jouko and V. Matti. Dose-response analysis of short-term effects of 2, 3, 7, 8- tetrachlorodibenzo-p-dioxin in three differentially susceptible rat lines. Toxicol Appl Pharmacol. 187, 2003. 128-36.

[31] J. Czepiel, G. Biesiada, M. Gajda, W. Szczepañski, K. Szypu£a, Z. D¥browski and T. Mach. . The effect of TCDD on the rat liver in biochemical and histological assessment. Folia biologica (Kraków). 58 2010, 85-90.

[32] M. El-Habibi, M. Sirag and G. Edrees. Comparative effect between chitosan and chitosan-Cu complex on carbon-tetrachloride (CCl4) induced liver damage in rats. Egypt J Hosp Med. 36, 2009. 397 - 405.

[33] M. Osman, A. Fayed, I. Ghada, R. Mahmoud and M. Romeilah. Protective effects of chitosan, ascorbic acid and Gymnema Sylvestre against hypercholesterolemia in male rats. Austr J Bas Appl Sci. 4, 2010. 89- 98.

[34] N. Fletcher, D. Wahlstorm, R. Lunberg, C. Nilsson, K. Nilsson, K. Stockling, H. Hellmold and H. Hakanson. 2, 3, 7, 8tetrachlorodibenzop-dioxin (TCDD) alters the m RNA expression of critical genes associated with cholesterol metabolism, bile acid biosynthesis and the transport of rat liver, A micro array study. Toxicol Appl Pharmacol. 207, 2005. 1- 24.

[35] WHO/IPCS. World Health Organization/International Programme on Chemical Safety. Polychlorinated dibenzo-p-dioxins and dibenzofurans. 1989. Environmental Health Criteria 88.

[36] O. James, H. Myron and N. Robert. Toxicity of 2, 3, 7, 8-tetrachlorodibenzo-p-dioxin in the Golden Syrian hamster. Toxicol Appl Pharmacol. 55, 1980.: 67-78. 
[37] W. Michael, F. Warren, Y. Edward, M. Avril, L. Karen, A. Yagminas, B, David, F. Michel, D. Daniel and H. Claude. Effects of sub-chronic exposure to a complex mixture of persistent contaminants in male rats: systemic, immune, and reproductive effect. Toxicol Sci. 67, 2002.131-43.

[38] I. Chu, P. Lecavalier, H. Hakansson, A. Yagminas, E. Valli, P. Poon and A. Feeley. Mixture effects of 2, 3, 7, 8-tetrachlorodibenzop-dioxin and polychlorinated biphenyl congeners in rats. J. Chemosphere. 43, 2001.807-14.

[39] A. Mustafa, S. Hollada, M. Goff, S. Witonsk, R. Kerr, C. Reilly, D, Sponenberg and R. Gogal. Postnatal autoimmune profile in 24 week -old C57BL/6 mice developmentally exposed to TCDD. Toxicol Appl Pharmacol. 232, 2008. 51- 59.

[40] C. Subhankari, M. Santanu, S. Sumanta, P. Panchanan and R. Somenath. Antioxidative effect of folate-modified chitosan nanoparticles. Paci J Tropi Biomed. 1, 2011. 29-38. 